J. Environ. Sci.

Institute of Environmental Studies and Research - Ain Shams University

\title{
A MODIFIED DIGESTER PROTOTYPE TO PRODUCE BIOGAS FROM SOME AGRICULTURAL WASTES AS A RENEWABLE ENERGY RESOURCE
}

Samir A. Demetry ${ }^{(1)}$; Mohammad A. El- Samanoudy ${ }^{(2)}$, Ali A. Ali(3); Hesham I. El-Kassas ${ }^{(4)}$ and Taha A. M. Abdel Razek ${ }^{(4)}$

1) Post-graduate student, Institute of Environmental Studies and Research, Ain Shams University 2) Faculty of Engineering, Ain Shams University 3) Faculty of Agriculture, Ain Shams University 4) Institute of Environmental Studies and Research, Ain Shams University

\begin{abstract}
The world is rapidly depleting its supply of natural gas as one of the fossil fuels. At the same time there are millions of tons of biomass waste being produced every year which disposal is a problem. Biomass waste including Water hyacinth (WH), cow manure (CM) and most of the organic wastes due to their organic compositions, they have a great potential for biogas production. In this study Anaerobic Digestion technology (AD) a highly promising technology is used to convert Water hyacinth and Cow manure into biogas as a resource of energy. Lab-scale experiments were carried out on some blends of fresh Cow manure collected from cow breeding farm and some of Water hyacinth harvested from Nile River. Composition analyses of raw materials were carried out using Walkley and Black methods and Kjeldal method. Lab-scale experiments were carried out to get the best conditions for producing the biogas. All experiments on biogas productivity were conducted till the yield of biogas significantly decreased.

By using a feed stock of WH containing $30 \mathrm{~g}$ TS/L for 30 days at constant temperatures namely $25^{\circ} \mathrm{C}, 37^{\circ} \mathrm{C}$ and $45^{\circ} \mathrm{C}$, it was found that the yield of biogas production yield at $37^{\circ} \mathrm{C}$ was more as compared to the other two temperatures $25^{\circ} \mathrm{C}, 45^{\circ} \mathrm{C}$. The biogas production yields at $25^{\circ} \mathrm{C}, 37^{\circ} \mathrm{C}$ and $45^{\circ} \mathrm{C}$ were $200 \mathrm{ml}, 390 \mathrm{ml}$ and $270 \mathrm{ml}$ respectively.
\end{abstract}


For different Water hyacinth and Cow manure blends with different Carbon/ Nitrogen ratios (C/N) namely, $\left(\mathrm{CN}_{20}, \mathrm{CN}_{25}\right.$, and $\left.\mathrm{CN}_{30}\right)$ the experiments were conducted for 30 days at temperature $37^{\circ} \mathrm{C}$. The results showed that the yield of Biogas in descending order for $\mathrm{CN}_{30}, \mathrm{CN}_{25}$ and $\mathrm{CN}_{20}$, were $350 \mathrm{ml}, 330 \mathrm{ml}$ and $300 \mathrm{ml}$ respectively. Also experiments showed that co-digestion is more productive for biogas production than mono-digestion. Slurry of WH of $50 \mathrm{~g}$ TS/1 inoculated by CM with rate of $10 \%(\mathrm{v} / \mathrm{v})$, the gas yield increased from $230 \mathrm{l} / \mathrm{kg}$ TS to $4201 / \mathrm{kg}$ TS as compared to the uninoculated slurry at same conditions. By charging the mobile digester by some blends of Water hyacinth and Cow manure (100\% CM; 75\% $\mathrm{CM}+$ $25 \% \mathrm{WH} ; 50 \% \mathrm{CM}+50 \% \mathrm{WH} ; 25 \% \mathrm{CM}+75 \% \mathrm{WH}$; and $100 \% \mathrm{WH})$ biogas were produced as results of treatment $(122 \mathrm{~L}, 148 \mathrm{~L}, 176 \mathrm{~L}, 153 \mathrm{~L}$, and $171 \mathrm{~L}$ respectively). The contents of methane gas in biogas were between 50-60\%.

The experiments results revealed that bio-organic materials could be potential sources for biogas production. Using a mobile digester will have double advantages. The first is generating biogas on site. Second is disposal of biomass wastes.

Key words: Biogas, Mobile Digester, Co-digestion, Organic wastes and Water hyacinth, Cow manure.

\section{INTRODUCTION}

As a result of negative environmental effects such as global warming and air pollution associated with energy production based on fossil fuels, the interest in alternative, cleaner and more sustainable energy sources, such as biogas, is growing rapidly (Adelard and Poulsen, 2015; Mao et al., 2015). In Egypt a strategic plan for renewable energy development has been established science 2014. Egypt intends to supply $20 \%$ of generated electricity from renewable sources by 2022 . 
When organic matter undergoes decomposition in absence of free oxygen, it normally generates a biogas. Biogas consists of methane, carbon dioxide and traces of other gases. Biogas has good calorific value and can be directly used as fuel or indirectly used to generate electricity.

For any biomass substrates there are some factors affecting its anaerobic digestion process. Any biomass is composed of total solids and water. The total solids are composed of fixed solids and volatile solids. Fixed solids are those that cannot be broken down during the digestion process, while volatile solids are those that are attacked by micro-organisms to yield biogas. The choice of a substrate depends on its availability, its cost, ease of handling, safety for operators, storage and requirements for feeding. In case of using one substrate it called Mono- digestion process. In case of using two substrates or more the process is called Co-digestion. Studies have shown that co-digestion of several substrates, have resulted in improved methane yield compared to that obtained from single substrates (Li et al., 2015; Yong et al., 2015 and Zarkadas et al., 2015). The relative proportions of carbon and nitrogen present in an organic material is expressed in terms of the (carbon/nitrogen) $\mathrm{C} / \mathrm{N}$ ratio. $\mathrm{C} / \mathrm{N}$ ratio in the range of $20-30$ is considered to be optimum for anaerobic digestion. Different species of methanogenic bacteria function optimally in three different temperature ranges: $50-65^{\circ} \mathrm{C}$, $20-40^{\circ} \mathrm{C}$, and $<10^{\circ} \mathrm{C}$, the concerned bacteria are called thermophilic, mesophilic, and psychrophilic, respectively. Optimum biogas production is achieved when the $\mathrm{pH}$ value of the mixture is between 6 and 7 . Retention time is the duration for which organic material (substrate) and microorganisms must remain together in a digester to achieve the desired 
extent of degradation. Agitation is required to maintain mixture in homogeneity, avoid or disrupt scum and sediment formation and release of biogas bubbles trapped in the substrate. Agitation is important for the distribution of heat throughout the digester. If a material is diluted too much, the solid particles may settle down in the digester and may not get degraded properly. If the slurry is too thick, it may be difficult to stir and may impede the flow of gas to the upper part of the digester (Ludwig, 1988).

Mineral ions, especially of heavy metals, and detergents are among the materials that inhibit the normal growth of bacteria in a digester. The mechanical, thermal, chemical or thermo-chemical pre-treatment of biomass prior to digestion can improve $\mathrm{CH}_{4}$ yield (Rodríguez-Abalde et al., 2011).

Depending on the feeding mode and consistency of the substrate, three main types of digestion systems can be distinguished, discontinuous digesters (batch), Continuous reactors and semi-continuous digester. The simplicity of the operating procedures of batch reactors installations is an advantage for popularizing its use.

Sources of wastes can be broadly classified into four types, Industrial, Commercial, Domestic, and Agricultural. Commonly waste is classified into two types, Biodegradable and Non-biodegradable waste. In general, all types of biomass are biodegradable and could be used as substrates as long as they contain carbohydrates, proteins, fats, cellulose and hemicellulose as main components.

Water hyacinth is listed as one of the most productive plants on earth and is considered one of the world's worst aquatic plants (Anushree, 2007). $\mathrm{WH}$ is considered as an aquatic problem damaging the environment, 
J. Environ. Sci.

Institute of Environmental Studies and Research - Ain Shams University

irrigation systems and crops (Mathur et al., 2004). Water hyacinth is blamed for reduction of biodiversity and increased evapotranspiration. It also acts as a good breeding place for mosquitoes, snails and snakes (Mironga, 2004). It interferes with navigation, recreation, irrigation, and power generation. Cow manure emits unpleasant odors. It emits greenhouse gases; including ammonia, VOCs, hydrogen sulfide and nitrous oxide (Mudasser, et al., 2015). These emissions can cause health problems in humans (National Research Council, 2003). Besides polluting the air, ammonia emissions from manure can contaminate ground water and cause also eutrophication (Ruile, et al., 2015).

The present study aims to design and fabricate a portable digester to produce biogas using different substrates of alternative feed stocks. On the other hand by using agricultural wastes for biogas producing and to eliminates the volume of waste.

\section{MATERIAL AND METHODS}

\section{Substrates:}

Water hyacinth: Some of young Water hyacinth was harvested from Nile River during March month.

Cow manure: Wet Cow manure was collected from cow breeding farm nearby faculty of Agriculture, Ain Shames University, Egypt.

Composition of the substrates: Chemical composition analysis of Water hyacinth and Cow manure were done by using Walkley and Black 
methods (Walkley, 1946). Kjeldal method was used to determine the total nitrogen and hence Carbon/ Nitrogen ratio $(\mathrm{C} / \mathrm{N})$.

Substrate preperation: To start experiments whole plants were washed thoroughly from grit and mud with tap water. To make the WH parts be available to microorganisms, pretreatments were applied. Two pretreatments were done to $\mathrm{WH}$. The first pretreatment was done by collecting Water hyacinth and chopping it into $0.5-1.5 \mathrm{~cm}$ pieces manually. Then the $\mathrm{WH}$ was air dried at ambient temperature (about $25^{\circ} \mathrm{C} \pm 4^{\circ} \mathrm{C}$ ) up to unchanged weight. The second pretreatment was done by chopping stems and leaves by electric chopper to get WH in small pieces with diameter of 5 to $10 \mathrm{~mm}$.

Lab Scale (bench) experiments: To get the optimum conditions of the fermentation process, some Lab scale experiments (bench experiments) were done.

A laboratory scale digester system was made up of a large aspirator bottle. The volume was $2 \mathrm{~L}$. The bottle mouth was tightly closed with a rubber stopper carrying two glass tubes one serving as a feed inlet, the other its function was gas outlet. The gas outlet was connected to a T-shaped glass tube, one end of which was used for gas sampling and the other connected to displacement system for measuring gas volume. The displacement system consisted of two graduated flasks connected to each other. The bottle was put in a water bath at the required temperature.

An experiment carried out by using a feed stock of WH containing $30 \mathrm{~g}$ TS/L for 30 days at constant temperatures namely 25,37 and $45^{\circ} \mathrm{C}$. Another experiment was carried out by loading Lab scale digester by $\mathrm{WH}$ slurry containing $20 \mathrm{TS} / \mathrm{L}, 30 \mathrm{TS} / \mathrm{L}$ and $50 \mathrm{~g}$ TS/L for 30 days at temperature $37^{\circ} \mathrm{C}$. 
For different Water hyacinth Carbon/ Nitrogen ratios $(\mathrm{C} / \mathrm{N})$ namely, $\mathrm{CN}_{20}$, $\mathrm{CN}_{25}$, and $\mathrm{CN}_{30}$, the experiments were conducted in the period of 30 days at temperature $37^{\circ} \mathrm{C}$. Also experiments to show the effect of co-digestion on producing of biogas production was done by inoculated WH slurry with CM.

Pilot Scale experiments: After repeating the above experiments Trireplication, the pilot digester was charged by different blends of $\mathrm{WH}$ and $\mathrm{CM}$. Experiments using this digester were done at faculty of Agriculture, Ain Shames University (Shoubra El Khiema), Egypt. Referring to the results of Bench scale experiments main parameters were adjusted to get maximum biogas production.

Digester description: Digester is batch mobile one (Figure 1). The digester has a cylindrical vessel shape, with total capacity of $2 \mathrm{~m}^{3}$. The digester vessel is double wall made of stainless steel between them an isolation material. The upper vessel lid is in dome- shape.

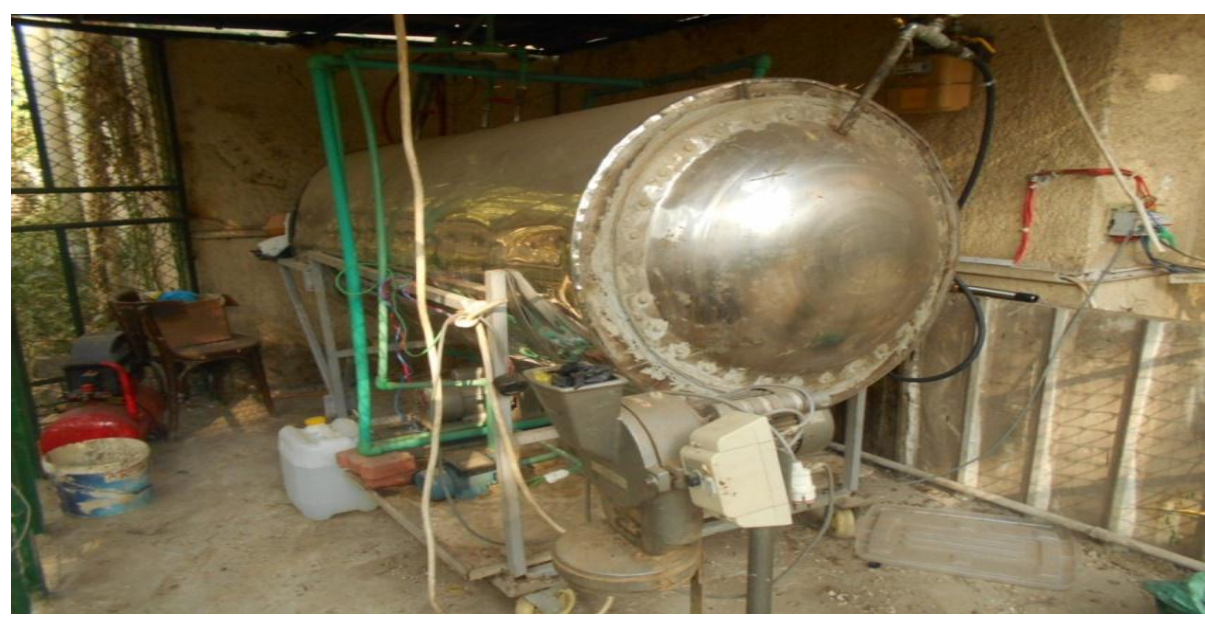

Figure (1): General view of digester and its attachments 
The digester was fed by influent by using an electrical gear pump. The ports of influent are controlled by manual valve made of stainless steel material. The effluent of the solid materials (digestate) could exit from the digester through a port at the bottom side of the digester. The substrate can be recycled by getting it from downstream through effluent orifice and pumping to the digester through the influent orifice. This helps to achieve a good mixing to the substrate inside the digester. The produced gasses might exit from the digester through one port at the lateral top side. The substrates inside digester were agitated by using internal stirrer; axial type. The stirrer was rotated by an electrical motor. To get a certain stirrers speed a reduction speed gearbox with reduction ratio $1 / 50$ was used. To control the agitation period a timer was adjusted to provide rotation to stirrer every hour for five minutes.

The substrates inside digester were heated by two spiral heating coils, inside these coils hot water was flow. Water was heated by electrical heater put inside a plastic container. The temperature of water was adjusted using a thermostat to the required temperature. The heated water was pumped to the water coils by an electric pump. The produced gases discharge from digester to biogas storage tank. The biogas line is controlled by non-return valve to prevent the return of biogas to inside the digester from biogas storage tank. Biogas storage tank was a set of 2 barrels made of plastic. The barrels were inversely positioned. The lower one was at right position and filled with water, while the other was inverted on the first one. The pressure of collected biogas exerts on water surface and it will lead to raise up the inverted barral and collecting the biogas inside it. 
Experimental setup: Five different blends with different mixing ratios were prepared from $\mathrm{CM}$ and $\mathrm{WH} .100 \% \mathrm{CM}+0 \% \mathrm{WH}$ (control treatment), $75 \%$ $\mathrm{CM}+25 \% \mathrm{WH}, 50 \% \mathrm{CM}+50 \% \mathrm{WH}, 25 \% \mathrm{CM}+75 \% \mathrm{WH}$ and $0 \% \mathrm{CM}+$ $100 \% \mathrm{WH}$. Every blend was diluted by water. Temperature was adjusted to be $37^{\circ} \mathrm{C}$ by using heated water which was controlled by a thermostat. Water was added to the substrates inside the digester to keep TS concentration as $50 \mathrm{~g} /$ Liter. $\mathrm{C} / \mathrm{N}$ of 30 was followed. $\mathrm{pH}$ was noticed to be kept at level 7. To maintain fluid homogeneity, hence process stability, stirrers were used inside the digester. A few minute of stirring is provided daily. Agitation offers advantages in fermentation process that is the substrates are kept in contact with the bacteria. To avoid the accumulation of the solids at the bottom of the tank, an exit orifice was used to draw the sediment substrate and pumped it again through the feeding port at the top side of the digester. The Retention Time was noticed till the gas production tends to be decreased which an indication that degradation of the substrates inside the digester is completed. The quantity of produced biogas was measured every two days. The quality of produced biogas was got by chemical analysis of biogas. The $\mathrm{CO}_{2}$ percentage in produced biogas was measured.

\section{RESULTS AND DISCUSSION}

Table (1): Chemical composition analysis of different parts of WH

\begin{tabular}{|c|c|c|c|}
\hline Plant part & Moisture\% & Volatile solids \% & Ash \\
\hline Roots & 91.2 & 63.6 & 36.4 \\
\hline Stem & 91.1 & 80.5 & 19.5 \\
\hline Leaf & 87.5 & 82.6 & 17.4 \\
\hline Average & 90.2 & 77.7 & 22.3 \\
\hline \multicolumn{4}{|c|}{ Vol. 47, No. 3, Sept. 2019 } \\
\hline
\end{tabular}


By examining these analyses it was found that the more suitable parts of WH are stems and leaves. Stems and leaves have higher volatile matter with lower ash contents than roots. So, by fermenting stems and leaves more biogas yield could be obtained than all the plant. To ensure lowest level of heavy metals contamination aerial parts (stems and leaves) of WH were only used (Antony et al., 2012).

With concern of the effect of the pretreatments methods, chopping and grinding of $\mathrm{WH}$, it was found no noticeable difference with concern with the composition of it as explained in (table 2). As a result of the similarly of the composition for the two treatments methods, the output results of experiments of chopped WH were only concerned.

Table (2): Chemical composition analysis of freshly and pretreated WH

\begin{tabular}{|c|c|c|}
\hline & $\begin{array}{c}\text { Freshly chopped WH } \\
\text { total plant }\end{array}$ & $\begin{array}{c}\text { Freshly ground WH } \\
\text { total plant }\end{array}$ \\
\hline \hline Moisture, \% w/w & 93.10 & 92.80 \\
\hline Total Solids, \%w/w & 6.90 & 7.20 \\
\hline \multicolumn{3}{|c|}{ On dry basis, \% w/w } \\
\hline Volatile solids & 74.00 & 74.00 \\
\hline Organic carbon & 32.40 & 29.00 \\
\hline Nitrogen & 1.20 & 1.30 \\
\hline
\end{tabular}

Table (3) demonstrates the chemical composition analysis of CM.

Table (3): Chemical composition analysis of CM

\begin{tabular}{|c|c|}
\hline Material & Composition \% \\
\hline \hline Moisture & 82.11 \\
\hline TS\% & 21.89 \\
\hline O.M.\% & 53.83 \\
\hline O .C.\% & 31.3 \\
\hline T.N.\% & 3.15 \\
\hline C/N & 9.936 \\
\hline
\end{tabular}


For the experiments carried at constant temperatures of $25^{\circ} \mathrm{C}, 37^{\circ} \mathrm{C}$ and $45^{\circ} \mathrm{C}$, the gas yield volume was $200 \mathrm{ml}, 390 \mathrm{ml}$ and $270 \mathrm{ml}$ respectively. So it cleared that the biogas production yield at $37^{\circ} \mathrm{C}$ was more as compared to the other two temperatures $\left(25^{\circ} \mathrm{C}, 45^{\circ} \mathrm{C}\right)$. By loading Lab scale digesters by $\mathrm{WH}$ slurry containing different concentration, 20, 30 and $50 \mathrm{~g}$ TS/L it gave cumulative biogases yield volume $530 \mathrm{ml} / \mathrm{kg}$ TS, $590 \mathrm{ml} / \mathrm{kg}$ TS $650 \mathrm{ml} / \mathrm{kg}$ TS respectively. So gas yield per unit weight of solids is directly proportional to the solids concentration. This result is due to when solid wastes like WH are put into digesters, and due to their low density in the dry state (0.3$0.4 \mathrm{~g} / \mathrm{cm}^{3}$ ) or due to buoyancy attained by the adhering gas bubbles will float above the liquid surface and become unavailable for digestion. The effect of the inoculumation on biogas production yield was cleared by carrying out experiments. By filling two Lab scale digesters, one of them with WH slurry of $50 \mathrm{~g}$ TS/1 with CM as inoculum with rate of $10 \%(\mathrm{v} / \mathrm{v})$ and second digester served as an uninoculated control (CO). Experiments were run for 30 days at temperature $37^{\circ} \mathrm{C}$. Regarding biogas yield per $\mathrm{kg}$ TS it was found the value which was giving by fermentation of (CO) was $2301 / \mathrm{kg}$ TS while the biogas yield per $\mathrm{kg}$ TS for the inoculated blend was 420 1/kg TS. So the co- digestion gives more biogas production than monodigestion.

To explain the effect of $\mathrm{C} / \mathrm{N}$ ratios on biogas production yield, three treatments were done at this work for different $\mathrm{C} / \mathrm{N}$ ratios of $\mathrm{WH}$ namely $\mathrm{CN}_{20}, \mathrm{CN}_{25}$ and $\mathrm{CN}_{30}$. The experiments were conducted in the period of 30 days and at temperature $37^{\circ} \mathrm{C}$. The results showed that the yield of Biogas in descending order for $\mathrm{CN}_{30}, \mathrm{CN}_{25}$ and $\mathrm{CN}_{20}$ respectively as $350 \mathrm{ml}, 330 \mathrm{ml}$ and $300 \mathrm{ml} .$. Regarding the average $\mathrm{pH}$ values produced among the treatments, 
showed that the $\mathrm{pH}$ value ranged from 6.9 to 7.1 without any need for external adjustment which is suitable for biogas digester operation. During digestion process the noticeable change in $\mathrm{pH}$ is mostly attributed to increase in the VFAs. In this study the produced VFAs were utilized for methane production. As a result there were negligible concentrations of VFAs to reduce the $\mathrm{pH}$ significantly.

\section{CONCLUSION}

Renewable energy generating and controlling waste disposal can be realized simultaneously through such fabricated digester. The merit of this mobile unit is that biogas production could be a continuous process in case that the substrates could be found. This mobile unit could overcome energy crisis in developing countries to a certain extend.

The utilization of WH as feed stocks for producing biogas provides an innovative way of managing the invasion of the weed in freshwater bodies in an environmentally sound manner. Also, batch digesters require little labour daily attention. The study revealed that utilization of $\mathrm{WH}$ and $\mathrm{CM}$ as substrates for biogas production can $\mathrm{WH}$ is a very good biogas producer which needs minimal pretreatment to enhance the biogas yield and shortening of the retention time. The co-digestion appears to have a synergetic effect on both biogas and hence $\mathrm{CH}_{4}$ production. Co-digestion generally improved ultimate biogas yield compared to mono-digestion of the same biomass materials. The pretreatment facilitates the separation of hemicellulose, cellulose and lignin, so that complex carbohydrate molecule containing cellulose and hemicellulose can be broken down by enzymatic 
saccharification to simple sugars. The produced biogas from this fabricated digester could be sufficient to the usage of a family consists of six persons for a month per every batch. It could be used as a batch digester and as semi continuous one. By using this digester it could be got around one of disadvantages of the ordinary batch digesters, where the ordinary batch digesters have a large foot print while this portable design has small foot print.

\section{RECOMMENDATION}

Further improvement of biogas yield and process flexibility in terms of various feed stocks is necessary. More experiments could be carried by using digester as a semi continuous digester. Other different materials could be used as substrates. The results of produced biogas should be recorded for different blends. It allows using secondary products obtained from agriculture, food industry waste, household waste, and animal manure from livestock. Replacing solar energy instead of electrical power to heat the used water. It also could be used to drive the attached electrical devices, like agitator motor and feeding pump. Issues involving the recovery of biomass energy and the decisions concerning the promotion of biogas technology in order to replace fossil fuel should be discussed in the general framework of the economy of the developed countries. 


\section{REFERENCES}

Adelard L.; Poulsen and T. G. (2015): Biogas and methane yield in response to co and separate digestion of biomass wastes. Waste Manage. Res. 33, 55-62.

Antony, S.; Raja, C.; Lindon Robert Lee and Int. J. Chem. Res. (2012): v02i4 (15-24).

Anushree Malik. (2007): Environmental challenge vis a vis opportunity: The case of water hyacinth, Environment International, 33, $122-138$.

Li D.; Liu S.C.; Mi L.; Li Z.D.; Yuan Y.X., Yan Z.Y. and Liu X.F. (2015): Effects of feedstock ratio and organic loading rate on the anaerobic mesophilic co-digestion of rice straw and cow manure, Bioresour. Technol. 189 (2015) 319-326.

Ludwig S. (1988): Biogas Plants, A Publication of the Deutsches Zentrum für Entwicklungstechnologien-gate. In: Deutsche Gesellschaft für Technische Zusammenarbeit (GTZ).

Mao C.; Feng, Y.; Wang, X.; Ren, G. (2015): Review on research achievements of biogas from anaerobic digestion. Renew. Sustain. Energy Rev. 45, 540-555.

Mathur S. M. and Singh P. (2004): Development and performance evaluation of a water hyacinth chopper cum crusher. Biosyst Eng; 88(4):411- 8.

Mironga J. M. (2004): Geographic information systems (GIS) and remote sensing in the management of shallow tropical lakes, Appl Ecol Environ Res 2(1), 83-103.

Mudasser M.; Yiridoe E. K. and Corscadden K. (2015): Cost-benefit analysis of gridconnected wind-biogas hybrid energy production, by turbine capacity and site, Renew. Energy 80, 573-582.

National Research Council: (2003). 
J. Environ. Sci.

Institute of Environmental Studies and Research - Ain Shams University

Rodríguez-Abalde A.; Fernándeza B.; Silvestre A. and Flotats G. X. (2011): Effects of thermal pre-treatments on solid slaughterhouse waste methane potential. Waste Manage. 31, 1488-1493.

Ruile S.; Schmitz S.; Monch-Tegeder M. and Oechsner H. (2015): Degradation efficiency of agricultural biogas plants - a full-scale study, Bioresour. Technol. 178,341-349.

Yong Z.; Dong Y.; Zhang X. and Tan T. (2015): Anaerobic co-digestion of food waste and straw for biogas production. Renew. Energy 78, 527-530.

Zarkadas I.S.; Sofikiti, A.S.; Voudrias E.A.; Pilidis G.A. (2015): Thermophilic anaerobic digestion of pasteurised food wastes and dairy cattle manure in batch and large volume laboratory digesters: focussing on mixing ratios. Renew. Energy 80, 432-440. 


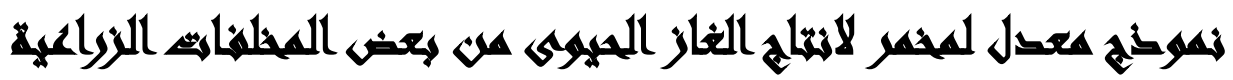

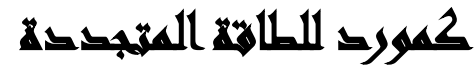

$[r]$

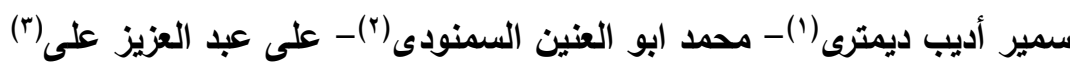

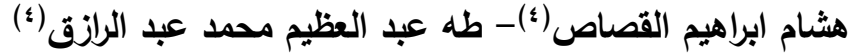

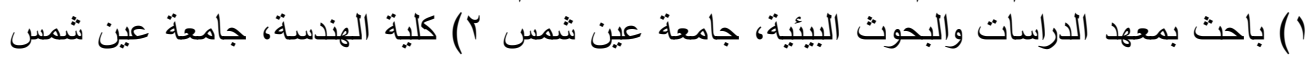

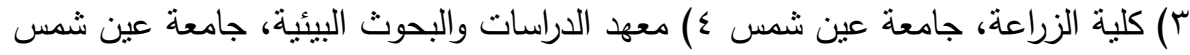

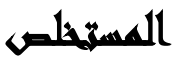

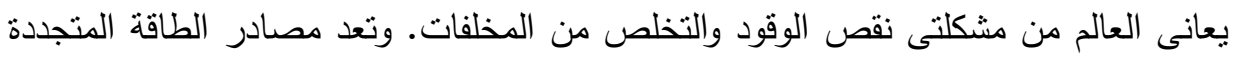

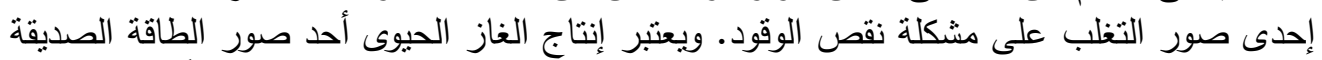

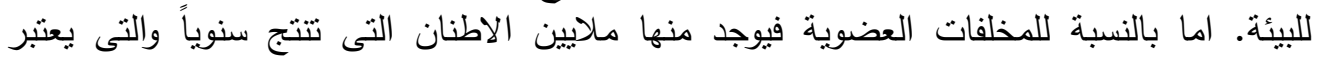

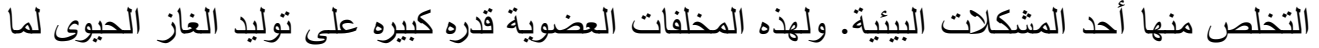
تحتويه من مكونات عضوية.

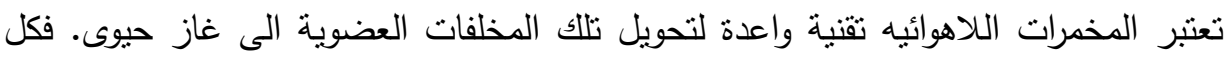

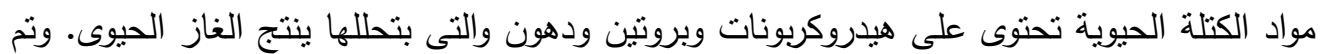

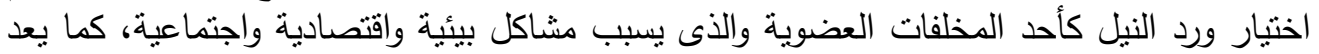

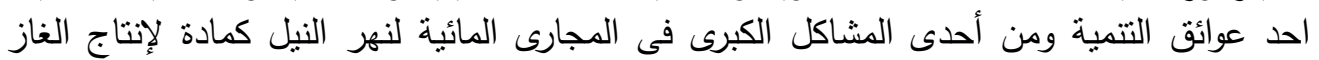

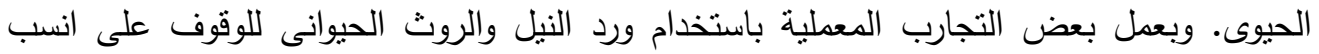

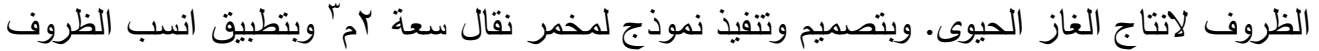

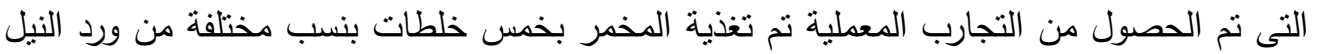

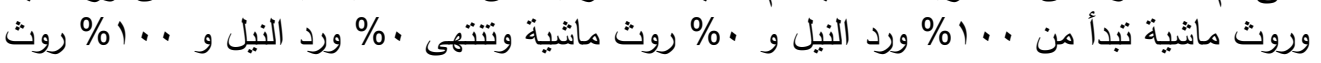

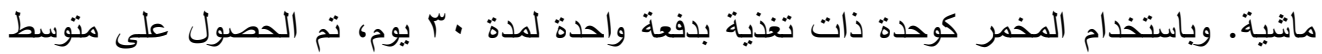

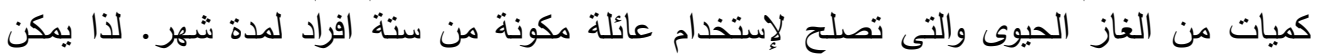

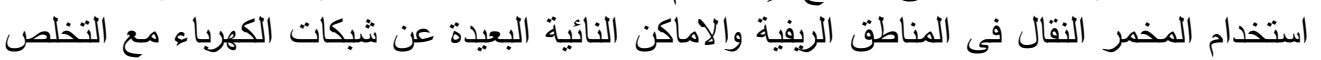
الآمن من المخلفات العضوية. الكلمات المفتاحية: الغاز الحيوى، مخمر نقال، التخمر المشترك، المخلفات العضوية، روث حيوانى، ورد النيل. 